\title{
Potensi ekstrak daun Carica pubescens sebagai alternatif antidiare Bakteri Vibrio cholerae dan Shigella dysentriae
}

\section{Potential of Carica pubescens leaf extract as alternative antidiare Bacteria for Vibrio cholerae and Shigella dysentriae}

\author{
Tri Dyah Astuti ${ }^{1 a^{\star}}$, Wahid Syamsul Hadi ${ }^{1 \mathrm{~b}}$ \\ 1 Universitas 'Aisyiyah Yogyakarta, Indonesia \\ aEmail address: tridyah@unisayogya.ac.id \\ bEmail address : dokterwahid@yahoo.co.id
}

\section{HIGHLIGHTS}

Carica Pubescens leaf extract with a concentration of $100 \%$ has a wider microbial inhibitory power

\section{ARTICLE INFO}

\section{Article history}

Received date : August $06^{\text {th }}, 2018$

Revised date : September $28^{\text {th }}, 2018$

Accepted date : December 31st 2018

\section{Keywords:}

Carica Pubescens

Vibrio cholerae

Shigella dysenteriae

In Vitro

\begin{abstract}
A B S T R A C T / A B S T R A K
Acute diarrhea is one of the main causes of morbidity and mortality. A people are starting to choose traditional medicines for alternative therapy. Traditional medicines or herbal medicines are considered safer and do not have side effects such as chemical drugs. The purpose of this study was to determine the anti-diarrhea effect of Carica pubescens leaf extract on the bacteria Vibrio cholerae and Shigella dysentriae. This study was conducted by testing the activity of Vibrio cholerae and Shigella dysentriae bacteria on Carica pubescens leaf extract with a well method, which results can be seen from the formation of inhibitory zones. The data obtained were processed using Two Way ANOVA test statistics. The results showed that the leaves extract of Carica Pubescens concentration of $100 \%$ had the best therapeutic effect because it had the greatest inhibitory power on the bacteria Vibrio cholerae and Shigella dysentriae.

Diare akut merupakan salah satu penyebab utama morbiditas dan mortalitas. Masyarakat mulai memilih obat tradisional atau obat herbal sebagai pengobatan alternatif. Obat tradisional atau obat herbal dinilai lebih aman dan tidak memberikan efek samping seperti obat kimia. Tujuan dari penelitian ini adalah untuk mengetahui efek anti diare ekstrak daun Carica pubescens terhadap bakteri Vibrio cholerae dan Shigella dysentriae. Penelitian ini dilakukan dengan menguji aktivitas bakteri Vibrio cholerae dan Shigella dysentriae terhadap ekstrak daun Carica pubescens dengan metode sumuran yang hasilnya dapat dilihat dari terbentuknya zona hambat. Data yang diperoleh diolah menggunakan statistik uji Two Way ANOVA. Hasil penelitian menunjukkan ekstrak daun Caricap pubescens konsentrasi $100 \%$ mempunyai efek terapi terbaik karena mempunyai daya hambat terbesar terhadap bakteri Vibrio cholerae maupun Shigella dysentriae.
\end{abstract}

Copyright (c) 2018 Jurnal Teknologi Laboratorium. All rights reserved 


\section{PENDAHULUAN}

Penyakit diare merupakan penyakit endemis di Indonesia dan merupakan penyakit potensial terjadi Kejadian Luar Biasa (KLB) yang dapat disertai dengan kematian. Pada tahun 2017 terjadi 7.077.299 kasus diare yang tersebar di seluruh indonesia. Provinsi jawa barat menempati kasus tertinggi penyakit diare sebanyak 1.297.021 dan disusul oleh jawa timur sekitar 1.060 .910 kasus diare. ${ }^{1}$

Diare akut merupakan salah satu penyebab utama morbiditas dan mortalitas pada anak di berbagai negara berkembang termasuk di Indonesia. Terdapat 60 juta diare akut setiap tahunnya di Indonesia, 1 - 5\% diantaranya akan menjadi diare kronik dan bila sampai terjadi dehidrasi berat yang tidak segara ditangani $50-60 \%$ diantaranya dapat meninggal dunia. ${ }^{2}$

Diare akut infeksi diklasifikasikan secara klinis dan patofisiologis menjadi diare non inflamasi dan diare inflamasi. Diare Inflamasi disebabkan invasi bakteri dan sitotoksin di kolon dengan manifestasi sindroma disentri dengan diare yang disertai lendir dan darah. Gejala klinis yang menyertai keluhan abdomen seperti mulas sampai nyeri seperti kolik, mual, muntah, demam, tenesmus, serta gejala dan tanda dehidrasi. Pada pemeriksaan tinja rutin secara makroskopis ditemukan lendir dan atau darah, serta mikroskopis ditemukan sel leukosit polimorfonuklear. ${ }^{3}$

Tingginya angka kesakitan diare tersebut dapat disebabkan karena foodborne infection dan waterborn infection oleh bakteri Shigella sp., Salmonella typhi, Salmonella parathypi, Campylobacter jejuni yang tergolong dalam bakteri invasif dan Entero Pathogenic Escherichia coli (EPEC), Staphylococcus aureus, Bacillus cereus, Clostridium prefingens, Vibrio cholerae yang tergolong dalam bakteri non invasif. ${ }^{4}$

Shigella dysenteriae termasuk dalam kelompok bakteri gram negatif, tidak berkapsul dan tidak membentuk spora, aerob fakultatif, memfermentasi glukosa dengan membentuk asam tetapi jarang memproduksi gas. ${ }^{5}$ Penyakit yang disebabkan oleh Shigella dysenteriae adalah disentri basiler, yaitu suatu infeksi peradangan akut saluran pencernaan, dengan kondisi kronis meliputi diare, buang air besar berair yang disertai darah, lendir, dan nanah. ${ }^{6}$

Vibrio cholerae merupakan bakteri yang berbentuk batang bengkok seperti koma, gram negatif, tidak berspora, hidup secara aerob atau anaerob fakultatif, bergerak melalui flagel yang monotrik, tidak membentuk spora, dan pada biakan tua dapat menjadi berbentuk batang lurus. ${ }^{7}$ Vibrio cholerae Salah satu bakteri yang menyebabkan diare dan biasanya diare yang ditimbulkan disebut dengan diare kolera. ${ }^{8}$

Seiring berkembangnya pengetahuan terdapat peningkatan kecenderungan penggunaan obat tradisional sebagai alternatif pengobatan. Hal tersebut akibat kecenderungan masyarakat untuk menerapkan hidup sehat kembali ke alam atau sering disebut dengan "back to nature". Selain itu, didorong oleh sangat kecilnya efek samping obat tradisional serta harganya yang terjangkau oleh semua masyarakat. ${ }^{9}$

Tanaman yang berpotensi dijadikan sebagai sumber obat salah satunya adalah Carica pubescens. Tanaman ini merupakan tanaman lokal di dataran tinggi Dieng. Penduduk setempat menyebutnya dengan sebutan karika. Tanaman ini berkerabat dekat dengan pepaya pada umumnya (Carica papaya). Namun, mempunyai karakteristik yang berbeda. Bagian tanaman karika yang paling banyak dimanfaatkan adalah buahnya. Daun karika dapat menyembuhkan penyakit akibat cacing kremi, demam malaria, beri- beri, sariawan, sembelit, dan disentri amuba. ${ }^{10}$ 
Buah tanaman ini mengandung zat antioksidan yang mampu menangkal bahaya radikal bebas dan mengandung enzim pencernaan yang meningkatkan kerja alat pencernaan, absorbsi nutrien, mengurangi stress pencernaan, menjaga $\mathrm{pH}$, menjaga kesehatan usus serta menyeimbangkan enzim-enzim alami tubuh. ${ }^{11}$

Berdasarkan hasil uji fitokimia daun Carica pubescens mengandung beberapa senyawa aktif seperti flavanoid, polifenol dan tanin, serta triterpenoid. ${ }^{12}$ Selain kandungan tersebut daun Carica pubescens juga memiliki kandungan senyawa aktif cystein protease dan papain. ${ }^{13}$ Senyawa aktif lainnya yang terkadung dalam Carica pubescens adalah saponin triterpen ${ }^{14}$ serta kandungan antioksidan, ${ }^{15}$ sedangkan senyawa aktif pada daun Carica pubescens yang berpotensi sebagai antimikrobia, antara lain flavonoid, alkaloid, tanin dan fenol. ${ }^{16}$

Alkaloid merupakan golongan senyawa yang bersifat basa yang mengandung satu atau lebih atom nitrogen dalam bentuk gabungan sebagai bagian dari sistem siklik. Alkaloid biasanya tidak berwarna dan berbentuk kristal. ${ }^{17}$ Alkaloid merupakan senyawa nitrogen heterosiklik, diketahui memiliki aktivitas antimikrobia secara in vivo. ${ }^{18}$

Flavonoid merupakan salah satu kelompok senyawa metabolit sekunder yang paling banyak ditemukan dalam semua tumbuhan berpembuluh, zat warna dalam bunga-bunga, batang maupun daun-daunan. Flavonoid berperan sebagai antioksidan dengan cara mendonasikan atom hidrogennya dan berada dalam bentuk glukosida atau dalam bentuk bebas yang disebut aglikon. ${ }^{19}$ Secara in vivo flavonoid berfungsi sebagai antimikrobia dengan membentuk kompleks dengan protein ekstraseluler yang terdapat pada dinding sel bakteri, dimungkinkan hal terseut menyebabkan rigiditas dari dinding sel mengalami penurunan. Sehingga mengakibatkan flavonoid mampu menerobos dinding sel. ${ }^{20}$

Tanin merupakan salah satu senyawa metabolit sekunder yang termasuk dalam golongan polifenol. Tanin mempunyai target pada polipeptida dinding sel sehingga pembentukan dinding sel menjadi kurang sempurna. Hal ini menyebabkan sel bakteri menjadi lisis karena tekanan osmotik maupun fisik sehingga sel bakteri akan mati. ${ }^{21}$ Senyawa fenolik merupakan senyawa yang penting karena merupakan kelas besar diantara senyawa-senyawa penyusun tanaman. Mekanisme antimikroba senyawa fenolik secara in vivo adalah dengan mengganggu kerja membran sitoplasma bakteri, termasuk diantaranya mengganggu transpor aktif dan kekuatan proton. ${ }^{22}$ Berdasarkan kandungan tersebut maka perlu dilakukan penelitian lebih lanjut potensi ekstrak daun Carica pubescens sebagai alternatif antidiare bakteri Vibrio cholerae dan Shigella dysentriae, serta belum adanya penelitian yang secara khusus menggunakan Karika dari Wonosobo sebagai alternative antidiaere menyebabkan penelitian ini perlu dilakukan.

\section{BAHAN DAN METODE PENELITIAN}

Penelitian ini merupakan penelitian eksperimen dengan menggunakan rancangan acak lengkap.

\subsection{Bahan dan alat penelitian}

Bahan yang digunakan adalah: ekstrak daun Carica pubescens, etanol $70 \%$, aquadest, Mueller Hinton Agar, kertas cakram steril, kertas cakram antibiotik, $\mathrm{NaCl}$ fisiologis, dietil sulfoksida 5\%, Brain Heart Infusion, bakteri Vibrio cholerae dan Shigella dysentriae. Peralatan yang digunakan berupa peralatan untuk ekstraksi. 


\subsection{Tahap penelitian}

\subsubsection{Preparasi pembuatan ekstrak daun Carica pubescens}

Daun Carica pubescens sebanyak $1 \mathrm{~kg}$ dipotong-potong kemudian dimasukkan kedalam binder pada suhu $\pm 45^{\circ} \mathrm{C}$ selama 24 jam. Daun yang sudah dibinder dihancurkan dengan blender sehingga menjadi serbuk daun carica yang halus. Serbuk daun carica selanjutnya dimasukkan dalam botol coklat sebanyak $200 \mathrm{~g}$ dan ditambah pelarut etanol $70 \%$ sebanyak $2 \mathrm{~L}$ dan digojok selama 3 hari. Daun carica setelah digojok dilanjutkan dengan tahap penyaringan menggunakan vacuum dan kain flanel, hasil penyaringan dilanjutkan lagi dengan penyaringan menggunakan kertas saring. Hasil penyaringan dilanjutkan dengan vacum evaporator untuk memisahkan etanol dengan ekstrak. Hasil ekstrak dilanjutkan lagi dengan dibinder selama 24 jam pada suhu $45^{\circ} \mathrm{C}$ untuk memekatkan hasil ekstraksi. Hasil ekstrasi selanjutkan dibuat kosentrasi $100 \%, 50 \%, 25 \%$, dan $12.5 \%$.

\subsubsection{Pembuatan Media dan Perbanyakan Bakteri}

Media Brain Heart Infusion digunakan untuk perbanyakan bakteri, sedangkan media yang digunakan untuk pengujian aktivitas adalah media Mueller Hinton Agar (MHA). Sebanyak $6 \mathrm{~g}$ media BHIB dilarutkan ke dalam $200 \mathrm{ml}$ akuades, dipanaskan hingga terlarut secara sempurna dan diatur $\mathrm{pH}$ nya pada kisaran $7,4 \pm 0,2$. Selanjutnya dituang dalam tabung reaksi. Sedangkan untuk media MHA, sebanyak $38 \mathrm{~g}$ media MHA dilarutkan dalam $1000 \mathrm{ml}$ akuades, dipanaskan hingga terlarut secara sempurna dan $\mathrm{pH}$ diatur pada kisaran 7,4 \pm 0,2 . Selanjutnya media tersebut disterilkan menggunakan autoklaf pada tekanan $1,5 \mathrm{~atm}$, suhu $121^{\circ} \mathrm{C}$ selama 15 menit. Setelah media disterilkan, selanjutnya media tersebut disimpan pada suhu $4^{\circ} \mathrm{C}$ dan siap digunakan. ${ }^{23}$

\subsubsection{Pembuatan Larutan Standart McFarland 0,5}

Sebanyak $0,5 \mathrm{~mL} \mathrm{BaCl} \cdot 2 \mathrm{H}_{2} \mathrm{O} 1,175 \%$ ditambah dengan $\mathrm{H}_{2} \mathrm{~S} 041 \%$ hingga volumenya $99,5 \mathrm{~mL}$ dan dihomogenkan. Kekeruhan dari larutan McFarland tersebut diperiksa dengan spektrofotometer dan diatur absorbansinya agar berada dalam kisaran 0,08-0,13 pada panjang gelombang $625 \mathrm{~nm}$. Larutan tersebut disegel dan disimpan dalam ruang gelap pada suhu kamar. Sebelum digunakan, larutan tersebut dihomogenkan dengan menggunakan vortex. Larutan McFarland tersebut akan dijadikan sebagai standart kekeruhan bakteri yang akan diuji aktivitasnya. ${ }^{24}$

\subsubsection{Penyiapan suspensi bakteri Vibrio cholerae dan Shigella dysentriae}

$\mathrm{BHI}$ cair sebanyak $5 \mathrm{ml}$ dimasukkan kedalam tabung reasi ditambahkan dengan tiga ose biakan bakteri selanjutnya di vortex. Hasilnya dibandingkan dengan

McFarland 0,5 dan diamati kekeruhan yang terjadi. Jika pada media $\mathrm{BHI}$ terlihat terlalu keruh dari McFarland maka ditambah lagi jumlah media $\mathrm{BHI}$ nya, jika kurang keruh maka ditambahkan lagi suspensi bakterinya.

\subsubsection{Uji aktivitas antibakteri}

Suspensi bakteri yang telah dibuat pada media BHI, dioleskan (swab) pada media MHA sampai rata menggunakan kapas lidi steril, selanjutnya dibuat sumuran dengan konsentrasi $12,5 \%, 25 \%, 50 \%$ dan $100 \% .{ }^{25}$ Dan dibuat kontrol positif berupa disk antibiotik serta kontrol negatif berupa pelarut ekstrak, yaitu dimethyl sulfoxide (DMSO). Selanjutnya biakan diinkubasi selama 24 jam pada suhu $37^{\circ} \mathrm{C}$. Daerah bening di sekitar sumuran yang berisi larutan uji diukur diameternya dengan menggunakan jangka sorong. Daerah bening tersebut 
mengindikasikan bahwa ekstrak memiliki kemampuan menghambat pertumbuhan bakteri uji. ${ }^{26}$

\subsubsection{Analisis data}

Diameter zona hambat ditunjukkan dengan adanya zona steril kemudian diukur menggunakan jangka sorong. Hasilnya kemudian dianalisis dengan uji Kolmogorov-Smirnov untuk melihat normalitas data. Kemudian dilanjutkan dengan uji ANOVA dua jalan karena ada dua faktor yang berpengaruh pada zona hambat. Dari uji ANOVA dua jalan dilanjutkan dengan uji Post Hoc Test untuk menentukan perlakuan yang terbaik yang sebelumnya sudah dilakukan uji kesamaan varian dengan uji Levene. Jika uji variannya sama maka dilanjutkan lagi dengan uji SNK (Uji Student Newman-Keuls).

\section{HASIL DAN PEMBAHASAN}

Bakteri Vibrio cholerae dan Shigella dysentriae diinokulasikan (streak plate) ke dalam media Mueller Hinton Agar (MHA) kemudian pada sumuran diisi dengan kertas cakram yang sudah direndam pada ekstrak daun Carica pubescens dengan kosentrasi $100 \%, 50 \%, 25 \%$ dan $12,5 \%$ dan disk antibiotik, kemudian dilanjutkan dengan inkubasi $37^{\circ} \mathrm{C}$ selama 24 jam. Hasil dari inokulasi adalah sebagai berikut

\begin{tabular}{lcccc}
\multicolumn{3}{l}{ Tabel 1. Hasil pengamatan zona hambat pada media plate } \\
\hline Bakteri & $\begin{array}{c}\text { Kosentasi } \\
(\%)\end{array}$ & \multicolumn{3}{c}{$\begin{array}{c}\text { Perlakuanke- } \\
\text { (cm) }\end{array}$} \\
& & 1 & 2 & 3 \\
\hline Vibrio cholera & 100 & 2,5 & 2,6 & 2,5 \\
& 50 & 2,0 & 2,3 & 2,2 \\
& 25 & 1,9 & 1,9 & 2,0 \\
& 12,5 & 1,8 & 1,8 & 1,9 \\
Shigella & Antibiotik & 2,5 & 2,5 & 2,5 \\
dysentriae & & & & \\
& 100 & 1,4 & 1,3 & 1,3 \\
& 50 & 0,7 & 0,8 & 0,8 \\
& 25 & 0,6 & 0,7 & 0,7 \\
& 12,5 & 0,7 & 0,6 & 0,6 \\
& Antibiotik & 1,7 & 1,7 & 1,7
\end{tabular}

Dari tabel 1 terlihat ada perbedaan zona hambat pada kosentrasi ekstrak daun Carica pubescens dari kosentrasi 100\%, 50\%, 25\%, dan 12,5\%. Gambaran hasil penelitian dari zona hambat bakteri Vibrio cholerae dan Shigela dysentriae dari tabel diatas dapat terlihat dari gambar 1 dan 2.

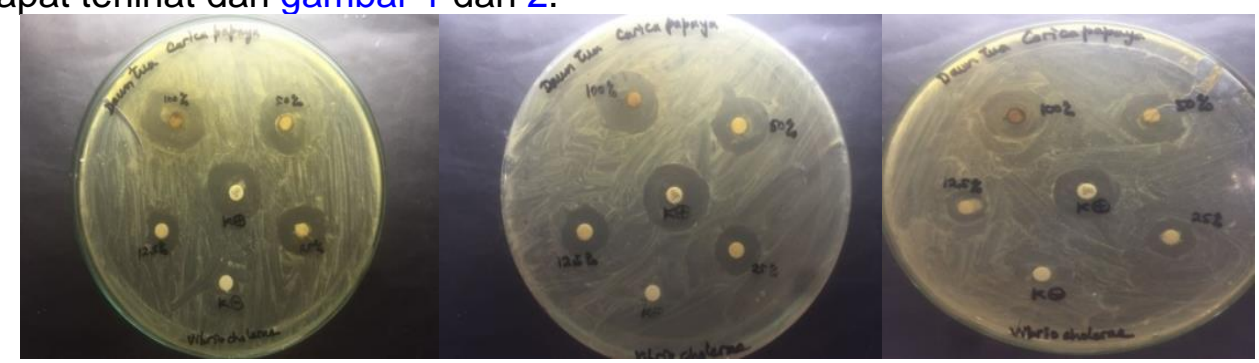

Gambar 1. Hail uji aktivitas zona hambat ekstrak Carica pubescens terhadap bakteri Vibrio cholerae

Sumber: Data primer (2018) 
Dari hasil sumuran diatas terlihat zona hambat terbaik yaitu pada kosentrasi $100 \%$ ekstrak daun Carica pubescens. Pada kosentrasi 100\% ekstrak daun Carica pubescens menunjukkan hasil yang hampir sama dengan zona hambat antibiotik. Dari gambar tersebut juga terlihat semakin kecil kosentrasi ekstrak daun Carica pubescens semakin kecil zona hambat terhadap bakteri Vibrio cholerae.

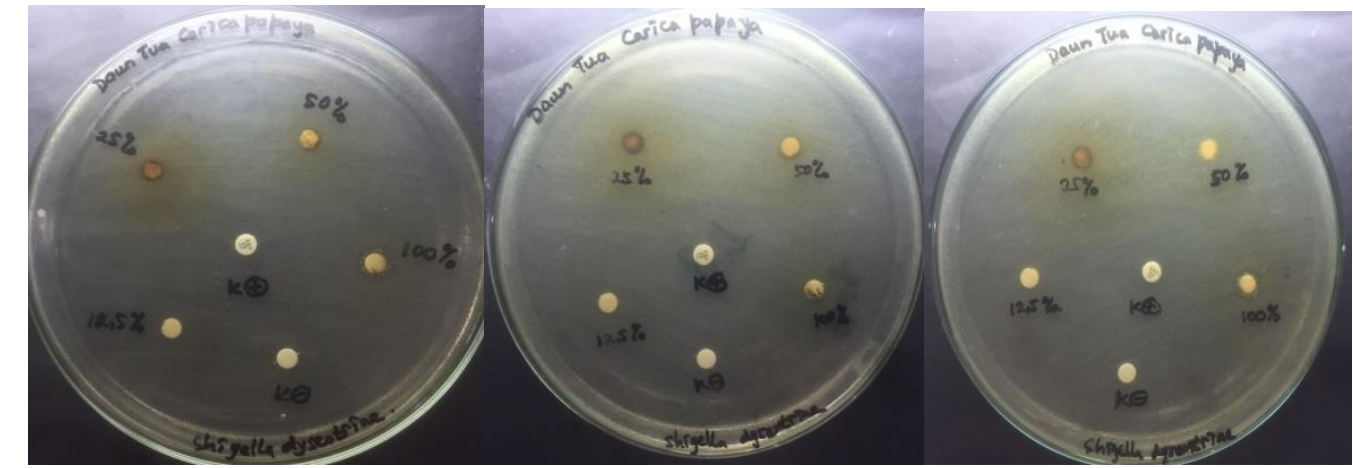

Gambar 2. Hail uji aktivitas zona hambat ekstrak Carica pubescens terhadap bakteri Shigela dysentriae.

Sumber: Data primer (2018)

Dari hasil sumuran terlihat zona hambat terbaik yaitu pada kosentrasi $100 \%$ ekstrak daun Carica pubescens. Pada konsentrasi $100 \%$ ekstrak daun Carica pubescens menunjukkan zona hambat yang lebih luas dari pada kosentrasi ekstrak daun Carica pubescens yang 50\%, 25\%, dan 12,5\% sehingga dapat disimpulkan bahwa semakin kecil kosentrasi ekstrak daun Carica pubescens semakin kecil zona hambat terhadap bakteri Vibrio cholerae.

\begin{tabular}{lcccc}
\multicolumn{4}{l}{ Tabel 2. Uji Two Way ANOVA } & \multicolumn{3}{l}{} \\
\hline Bakteri & $\begin{array}{c}\text { Kosentrasi } \\
\text { Ekstrak 12,5\% }\end{array}$ & $\begin{array}{c}\text { Kosentrasi } \\
\text { Ekstrak 25\% }\end{array}$ & $\begin{array}{c}\text { Kosentrasi } \\
\text { Ekstrak 50\% }\end{array}$ & $\begin{array}{c}\text { Kosentrasi } \\
\text { Ekstrak 100\% }\end{array}$ \\
\hline $\begin{array}{l}\text { Shigella } \\
\text { dysentri }\end{array}$ & 0,633 & 0,667 & 0,800 & 1,333 \\
$\begin{array}{l}\text { Vibrio } \\
\text { cholera }\end{array}$ & 1,833 & 1,867 & 2,167 & 2,533 \\
\hline
\end{tabular}

Dari tabel 2 terlihat pada konsentasi 100\% nilai rerata zona hambat Shigella dysentri $(1,333)$ dan Vibrio cholerae lebih besar $(2,533)$. Uji dilanjutan dengan uji SNK (uji Student Newman-Keuls). Hasil uji disajikan sebagai berikut:

Tabel 3. Hasil Uji Student Newman-Keuls

\begin{tabular}{ccccc}
\hline Kosentrasi $(\%)$ & Jumlah & Perlakuan 1 & Perlakuan 2 & Perlakuan 3 \\
\hline 12,5 & 6 & 1,233 & & \\
25 & 6 & 1,267 & & \\
50 & 6 & & 1,483 & \\
100 & 6 & & & 1,933 \\
Signifikansi & & 0,555 & 1,000 & 1,000 \\
\hline
\end{tabular}

Dari tabel 3 terlihat zona hambat akibat konsentrasi ekstrak daun Carica pubescens $100 \%$ adalah yang terbesar dan berbeda siginifkan dari konsentrasi lainnya. Maka kosentrasi $100 \%$ adalah paling efektif menghambat pertumbuhan bakteri Shigella dysentri dan Vibrio cholerae. Berdasarkan hasil zona hambat ekstrak daun 
Carica pubescens mampu menghambat pertumbuhan bakteri penyebab diare Shigella dysentri dan Vibrio cholerae, selain itu ektrak daun Carica pubescens juga mampu menghambat pertumbuhan bakteri penyebab diare lainnya seperti penelitian yang dilakukan oleh Novalina (2013) menyatakan ekstrak Carica pubescens mampu $B$. cereus, S. flexneri dan E. Coli. Ekstrak daun Carica pubescens dapat menghambat pertumbuhan bakteri karena terdapat kandungan tanin, alkaloid, fenol dan flavanoid.

Penelitian ini dengan penelitian yang dilakukan oleh Novalina (2013) memiliki persamaan pada variabel bebas yaitu menggunakan ekstrak daun Carica pubescens dengan kosentrasi $12,5 \%, 25 \%$, dan $50 \%$ untuk menghambat bakteri gram negatif $(E$. coli dan S. flexneri) penyebab diare. Penelitian yang telah dilakukan menunjukkan hasil zona hambat yang berbeda, sesuai dengan pereaksi yang digunakan dalam ekstraksi daun Carica pubescens. Pereaksi yang digunakan pada penelitian sebelumnya menggunakan Fraksi etil asetat dan n-heksan sedangkan penelitian ini menggunakan etanol $70 \%$. Hasil dari penelitian sebelumnya dengan menggunakan pereaksi n-heksan terhadap bakteri S. flexneri kosentrasi $12,5 \%$ zona hambat $0,6 \mathrm{~cm}$, kosentrasi $25 \%$ zona hambat $1,7 \mathrm{~cm}, 50 \%$ zona hambat $1,2 \mathrm{~cm}$. Bakteri E. coli kosentrasi $12,5 \%$ zona hambat $0,6 \mathrm{~cm}$, kosentrasi $25 \%$ zona hambat $1,0 \mathrm{~cm}, 50 \%$ zona hambat $0,8 \mathrm{~cm}$, sedangkan pada pereaksi etil asetat bakteri $S$. flexneri kosentrasi $12,5 \%$ zona hambat $2,2 \mathrm{~cm}$, kosentrasi $25 \%$ zona hambat $2,5 \mathrm{~cm}, 50 \%$ zona hambat $2,9 \mathrm{~cm}$. Bakteri $E$. coli kosentrasi $12,5 \%$ zona hambat $1,1 \mathrm{~cm}$, kosentrasi $25 \%$ zona hambat $1,3 \mathrm{~cm}, 50 \%$ zona hambat $1,6 \mathrm{~cm}$. Penelitian yang dilakukan peneliti menunjukkan hasil yang berbeda pada pereaksi etanol 70\% terhadap bakteri Shigella dysentri kosentrasi $12,5 \%$ zona hambat $0,7 \mathrm{~cm}$, kosentrasi $25 \%$ zona hambat $0,7 \mathrm{~cm}, 50 \%$ zona hambat $0,8 \mathrm{~cm}$, $100 \%$ zona hambat $1,4 \mathrm{~cm}$, sedangkan pada bakteri Vibrio cholerae kosentrasi $12,5 \%$ zona hambat $1,9 \mathrm{~cm}$, kosentrasi $25 \%$ zona hambat $2,0 \mathrm{~cm}, 50 \%$ zona hambat $2,3 \mathrm{~cm}$, $100 \%$ zona hambat $2,6 \mathrm{~cm}$.

Berdasarkan hasil penelitian menunjukkan bahwa ekstrak Carica pubescens dengan pereaksi dan kosentrasi yang berbeda memiliki efektivitas yang sama dalam menghambat pertumbuhan bakteri gram negatif penyebab diare.

\section{SIMPULAN}

Hasil uji potensi ekstrak daun Carica pubescens sebagai alternatif antidiare bakteri Vibrio cholerae dan Shigella dysentriae secara in vitro menunjukkan konsentrasi ekstrak daun Carica pubescens 100\% memiliki zona hambat yang terbesar dan berbeda siginifkan dari konsentrasi lainnya. Maka konsentrasi $100 \%$ adalah konsentrasi yang paling efektif menghambat pertumbuhan bakteri serta memiliki efek terapi terbaik bakteri Shigella dysentri maupun Vibrio cholerae.

\section{UCAPAN TERIMA KASIH}

Peneliti mengucapkan terima kasih kepada DIKTI yang telah membiayai penelitian ini melalui hibah Penelitian Dosen Pemula. Terima kasih kepada Universitas 'Aisyiyah Yogyakarta dan teknisi laboratorium yang telah membantu peneliti dalam menyelesaikan penelitian ini.

\section{DAFTAR PUSTAKA}

1. Kementerian Kesehatan Republik Indonesia. Profil Kesehatan Indonesia. Jakarta: Kementerian Kesehatan Republik Indonesia; 2017.

2. Daldiyono, Marcellus KS, PAPDI. Diare Akut:Buku Ajar Ilmu Penyakit Dalam. 5th ed. Jakarta: Fakultas Kedokteran Universitas Indonesia

3. Wilson WR, Drew WL, Henry NK. Current Diagnosis and Treatment in Infectious. New York: Lange Medical Books; 2003. 
4. Sudoyo A, Setyohadi B, Alwi I. Buku Ajar IImu Penyakit Dalam. 4th ed. Jakarta: Departemen IPD Fakultas Kedokteran Universitas Indonesia; 2006.

5. Dewi N. Kemampuan Daya Hambat Ekstrak Buah Mengkudu (Morinda citrifolia) terhadap Bakteri Shigella dysenteriae. Sainmatika. 2015;2(1):1-7.

6. Pelczar MJ, Chan CS. Dasar-Dasar Mikrobiologi. 1st ed. Jakarta; 1998.

7. Chomvarin C, Namwat W, Wongwajana S, Alam W, Thaew-Nonningiew K, Engchanil C. Application of duplex-PCR in rapid and reliable detection of toxigenic Vibrio cholerae in water samples in Thailand. Gen Appl Microbiol. 2007;53:229-237.

8. Soemarsono H. Kolera: Dalam Buku Ajar IImu Penyakit Dalam. Jakarta: Fakultas Kedokteran Universitas Indonesia; 1996.

9. Djauhariya E, Hernani. Gulma Berkhasiat Obat. Jakarta: Penebar Swadaya; 2004.

10. Hidayat S. Prospek Pepaya Gunung (Carica pubescens Lenne \& K. Koch) dari Sikunang, Pegunungan Dieng, Wonosobo. In: Menggali Potensi Dan Meningkatkan Prospek Tanaman Hortikultura Menjadi Ketahanan Pangan Dalam Rangka Hari Cinta Puspa Dan Satwa Nasional. Bogor: UPT Balai Pengembangan Kebun Raya-LIPI; 2000.

11. Rock R. Product Review - Wild Mountain Papaya Extract. http://www.associatedcontent.com/article/1987516/product_review_wild_mountai n_papaya.html.

12. Minarno B. Skrining Fitokimia dan Kandungan Total Flavonoid Pada Buah Carica Pubescens Lenne \& K. Koch di Kawasan Bromo, Cangar, dan Dataran Tinggi Dieng. Univ Islam Negeri Maulana Malik Ibrahim Malang. 2015;5(2).

13. Ainun NL, N. Khoiri Ahmad. Identifikasi Senyawa Antidiabetes Secara in Silico pada Carica Pubescens Lenne \& K. Koch. Univ Islam Negeri Maulana Malik Ibrahim Malang. 2016;5(4).

14. Minarno B. Analisis Kandungan Saponin Pada Daun dan Tangkai Daun Carica Pubescens Lenne \& K. Koch. Univ Islam Negeri Maulana Malik Ibrahim Malang. 2016;5(4).

15. Laily AN, Suranto, Sugiyarto. Characteristics of Carica pubescens of Dieng Plateau, Central Java according to its Morphology, Antioxidant, and Protein Pattern. Univ Sebel Maret Surakarta. 2012;4(1):16-21.

16. Novalina D. Aktivitas Antibakteri Ekstrak Daun Carica Pubescens dari Dataran Tinggi Dieng terhadap Bakteri Penyebab Penyakit Diare. Tesis. Universitas Sebelas Maret. 2013;1(1):1-12.

17. Fitriana S. Penapisan Fitokimia dan Uji Aktivitas Anthelmintik Ekstrak Daun Jarak (Jatropha curcas L.) terhadap Cacing Ascaridia galli secara in vitro. 2008.

18. Karou D. Antibacterial Activity of Alkaloids Arom Sida Acuta. African $J$ Biotechnol. 2006;5(2):195-200.

19. Harborne JB. Metode Fitokimia Penuntun Cara Modern Menganalisa Tumbuhan. 2nd ed. Bandung: Institut Teknologi Bandung; 2006.

20. Fitrial Y, Astawan M, Soekarto SS, Wiryawan KG, Wresdiyati T, Khairina R. Aktivitas Antibakteri Ekstrak Biji Teratai terhadap Bakteri Patogen Penyebab Diare. J Teknol dan Ind Pangan. 2008;19(2):158-164.

21. Sari FP, Sari SM. Ekstraksi Zat Aktif Antimikroba dari Tanaman Yodium (Jatropha Multifida Linn) sebagai Bahan Baku Alternatif Antibiotik Alami. 2011.

22. Harborne JB. Metode Fitokimia, Penuntun Cara Modern Menganalisis Tumbuhan. 2nd ed. (Kosasih P, Iwang S, eds.). Institut Teknologi Bandung; 1987.

23. Kumar GVP, Subrahmanyam SN. Phytochemical Analysis, in-vitro Screening for Antimicrobial and Anthelmintic Activity of Combined Hydroalcoholic Seed Extracts of Four Selected Folklore Indian Medicinal Plants. Sch Res Libr. 
2013;5(1):168-176.

24. European Committee on Antimicrobial Susceptibility Testing (EUCAST). Antimicrobial Susceptibility Testing: EUCAST Disk Diffusion Method.

25. Poeloengan M, Andriyani I, Komala, Hasnita M. Uji Antibakteri Ekstrak Etanol Kulit Batang Bungur (Largerstoremia speciosa Pers) terhadap Staphylococcus aureus dan Escherichia coli Secara In Vitro. In: Seminar Nasional Teknologi Perternakan Dan Veteriner. Bogor: Central Library of Bogor Agricultural University; 2007.

26. Ahmed D, Waheed A, Chaudhary MA, Khan SR, Hannan A, Barkaat M. Nutritional and Antimicrobial Studies on Leaves and Fruit of Carissa opaca Stapf Ex Haines. EJEAFChe. 2010;9(10):1631-1640. 